\title{
UTJECAJ FIN-TECH KOMPANIJA NA DIGITALNU TRANSFORMACIJU BANKARSTVA U REPUBLICI HRVATSKOJ
}

\author{
dr. sc. Sanja Bračun \\ Tehničko veleučilište u Zagrebu \\ Vrbik 8, Zagreb, Hrvatska \\ broj mobitela: +38599 2630703, e-mail: sbracun1@tvz.hr \\ Krešimir Turkalj, bacc. oec. \\ Sberbank \\ F. Račkog 9, Zagreb, Hrvatska \\ broj mobitela: +385916393443, e-mail: turkalj.kresimir@gmail.com
}

\section{SAŽETAK}

Digitalna transformacija financijskog sektora na globalnom tržištu snažno napreduje. Fin-Tech kompanije sve više konkuriraju ili čak u potpunosti zaobilaze postojeći financijski sektor, primarno banke. Taj trend vidljiv je i u Republici Hrvatskoj, gdje se sve više pojavljuju nova poduzeća i njihovi inovativni financijski proizvodi. U cilju provjere spremnosti hrvatskih banaka na digitalnu transformaciju te implementaciju novih proizvoda i usluga, kroz provedeno kvalitativno istraživanje (intervjui s deset relevantnih sugovornika iz područja bankarstva i Fin-Tech kompanija) provjeren je utjecaj Fin-Tech kompanija koji su van bankarskog sektora, na sam bankarski sustav. Dodatna je pozornost tijekom istraživanja posvećena procjeni jesu li banke i Fin-Tech kompanije na hrvatskom tržištu prepoznale aktualne potrebe svojih klijenata, koliko im se dobro prilagođavaju te mogu li banke $i$ dalje biti lideri u digitalnoj transformaciji Republike Hrvatske. Što se tiče prilagođavanja potrebama klijenata, manji dio sudionika istraživanja smatra kako će se portfelj usluga banaka tek nadopunjavati novim proizvodima i uslugama, dok ipak veći dio sudionika istraživanja smatra kako će u idućih 5 godina, postojeće prvenstveno platno prometne usluge banaka i kartičarskih kuća biti zamijenjene posve novim poslovnim modelima. Predstavnici banaka uočavaju jak utjecaj Fin-Tech kompanija na globalnom tržištu, no smatraju da u Republici Hrvatskoj oni ipak imaju manji utjecaj. Također, smatraju da se banke generalno dobro prilagođavaju novoj situaciji te da će i dalje ostati lideri digitalne transformacije. Tu poziciju zadržat će prvenstveno zbog svoje veličine i količine kapitala kojom raspolažu u procesu izgradnje percepcije sigurnosti svog poslovanja koja je hrvatskim korisnicima i dalje iznimno bitna. Na temelju rezultata provedenog istraživanja dane su preporuke daljnjih aktivnosti vezenih uz digitalnu transformaciju, koje bi banke trebale provesti u cilju zadržavanja vodeće pozicije na hrvatskom tržištu financijskih usluga. 


\section{UVOD}

Tehnološki razvoj u svim segmentima poslovanja donosi velike promjene, pa tako i u bankarstvu. Tu se ne misli samo na uvođenje novih tehnologija u postojeće procese, poput internet i mobilnog bankarstva, nego sasvim drugačije izazove s kojima se bankarska industrija u zadnje vrijeme sve više susreće - novim proizvodima Fin-Tech kompanija, koje preuzimaju inicijativu u području dosad rezerviranom isključivo za banke. Pored Fin-Tech kompanija, tu su i veliki nefinancijski informatički divovi (Big-Tech) poput Google-a, Amazon-a i Alibaba-e koji također u financijskom području vide dodatnu poslovnu priliku. Dodatnu prednost im daju raspoloživi resursi, inovativne tehnološke ideje kao i patenti s kojima se banke sve teže bore, a u budućnosti bi im mogli predstavljati još veći izazov. Blockchain tehnologija, novi oblici novca (digitalne valute), virtualne kartice, roboti i umjetna inteligencija snažno utječu na financijsko tržište, a u godinama koje dolaze njihov utjecaj biti će još značajniji. Upravo je to razlog zašto banke ukoliko žele opstati, moraju vrlo brzo i pametno integrirati tehnološke novitete u svoje poslovne procese.

Poziciju važnog izazivača koju su Fin-Tech kompanije donedavno imale, kao i globalnu ekonomiju, narušila je pandemija Korona virusa. Dok veliki investitori nastoje što prije likvidirati svoju imovinu, Fin-Tech kompanije sada su prisiljene značajno smanjivati troškove kako bi opstale. Prije krize koju je izazvao Covid-19, samo je manji broj Fin-Tech kompanija bio profitabilan, dok se većina njih fokusirala isključivo na rast poslovanja s velikim investitorima (Zachariadis i sur., 2020). Kao što je Fin-Tech revolucija djelomično i nastala iz pepela prethodne globalne financijske krize, za očekivati je da će te kompanije i sada znati kako brzo i fleksibilno reagirati na nesigurnost u kojoj su se našle.

Fin-Tech kompanije na hrvatskom su tržištu do sada primarno ulazile samo u sferu platnog prometa i novčanih transakcija te kartičnog poslovanja. Znajući da svaka uspješna bankarska strategija mora prepoznati operativno efikasnije poslovne modele, koji uključuju osvajanje novih segmenata klijenata i uvođenje novih usluga koje stvaraju dodatne izvore prihoda (AtKearney, 2014), za očekivati je da će su i tu situacija ubrzo promijeniti. Za banke u Republici Hrvatskoj (RH) to znači da svoje poslovanje trebaju ubrzano prilagođavati, osobito u sferi grupnog financiranja i algoritamskih procjena rizika i skoringa klijenata, kao i novim tehnologijama s obzirom da ne postoji vremenski odmak za prilagodbu.

\section{FIN-TECH - POJAM I KARAKTERISTIKE}

Globalno investiranje u Fin-Tech kompanije kontinuirano raste i sve više transformira bankarsku industriju smanjujući prihode klasičnih financijskih institucija (KPMG, 2019). U svojoj osnovi Fin-Tech koristi digitalnu tehnologiju, koja omogućava uvođenje tehnoloških inovacija u obliku novih financijskih proizvoda te brze i automatizirane financijske usluge poput platformi za direktno kreditiranje (direct lending, P2P) i financije digitalnih valuta (Blockchain i digital currency tehnologije). Istovremeno, u mnoga financijska područja sve više uvode primjenu umjetne inteligencije i algoritama (trgovanje vrijednosnicama, procjenu rizika, upravljanje imovinom i sl.). Dodatna im je karakteristika da se obraćaju direktno korisnicima svojih financijskih usluga, često uz bržu, jednostavniju i jeftiniju uslugu, nego što to čine banke (Krstić i Tešić, 2016). U te su procese osim Fin-Tech i Big-Tech kompanija, uključene i klasične financijske institucije, koje su prepoznale ne samo opasnost 
za svoje tradicionalno poslovanje, već i priliku da se i direktno uključe u tehnološku utrku kako bi i same postale jedan od značajnijih ulagača u Fin-Tech na globalnom nivou.

\subsection{Fin-Tech počeci i razvoj u svijetu}

Kada se spomene Fin-Tech, gotovo svi automatski pomisle na digitalne tehnologije, pametne telefone, robote i slično, no sami počeci Fin-Tech-a u širem smislu zapravo sežu u 50-te godine 20. stoljeća (Desai, 2015), kada se tehnologija počinje upotrebljavati kako bi olakšala, pojednostavila i ubrzala financijske procese i usluge unutar banaka. Prvu primjenu Fin-Tech tehnologija povezujemo s izdavanjem kreditnih kartica i uvođenjem plaćanja bez gotovine, što se dodatno proširilo i s uvođenjem bankomata. Promjene i opseg korištenja tehnologije sve se više povećava unutar financijskog sektora, kada ulaze u domene kao što su burze i trgovanje vrijednosnicama, a kasnije se počinju širiti i na internet zajedno s uzletom sustava za e-trgovanje. Na institucionalnom nivou, značajne promjene dešavale su se i unutar samih banaka. Kontinuirano se unapređuju procesi i načini korištenja tehnologije kako bi se značajno bolje upravljalo imovinom, rizicima, trgovanjem i ostalim aktivnostima. U tom segmentu javljaju se i jaki nebankarski igrači koji imaju značajnu ulogu u institucionalnoj infrastrukturi, kao što su npr. Bloomberg, Thomson Reuters, Misys i drugi (Wonglimpiyarat, 2017). Kako tehnologija ubrzano napreduje, pojavljuje se sve više novih mogućnosti, a pristup komunikacijskoj infrastrukturi putem interneta i mobilnih mreža ubrzano povezuje korisnike i cijeli moderni svijet u globalno tržište.

Na taj način su se područja primjene digitalnih tehnologija u financijskom sektoru ubrzano širila te stvorila veliku mrežu mogućnosti, raznolikosti i ogromnog broja Fin-Tech kompanija i aplikacija. Danas već koristimo digitalizirane mobilne novčanike, virtualizirane kartice, aplikacije za trenutačna plaćanja i namiru, robo savjetnike koji pomažu u financijskom savjetovanju za planiranje štednje, kumulacije kapitala ili za planiranje mirovine. Također sve se češće koriste i platforme za prikupljanje grupnog dioničkog kapitala poduzeća (equity crowdfunding platforms), za online kreditiranje klijenata, za alternativna ulaganja, pa naposljetku i za alternativni novac odnosno digitalne kriptovalute.

\subsection{Fin-Tech u Republici Hrvatskoj}

Republika Hrvatska u područje primjene Fin-Tech tehnologija ulazi relativno kasno i u relativno ograničenom opsegu. Hrvatsko financijsko tržište je orijentirano i organizirano kroz komercijalne banke pa bankarsku industriju možemo smatrati zrelom industrijom u fazi konsolidacije, koja je do prije nekoliko godina bila nespremna na disruptivne promjene koje za sobom donosi Fin-Tech i pripadajuće promjene u tehnologiji i njenoj primjeni. S obzirom da je Fin-Tech po samoj svojoj pojavnosti globalni biznis, koji ne pozna granice država, u posljednjih se nekoliko godina i u RH sve više šire Fin-Tech rješenja.

To su ponajprije strane kompanije s globalnim uslugama koje su prvo počeli koristiti korisnici skloni internet kupnji. U tu svrhu prvenstveno se koristi PayPal koji je od 2011. g. dostupan u $\mathrm{RH}$, a danas ga podržava većina hrvatskih banaka kroz korištenje njihovih kreditnih kartica za plaćanje putem interneta. Jedna od većih stranih Fin-Tech kompanija čija je usluga također dostupna u RH je i on-line banka Revolut, koja je u samo nekoliko mjeseci uspjela dostići više od 50.000 korisnika. „Revolut je prije četiri godine bio zamišljen 
kao kartica za putovanja kod koje su svi troškovi koji nastaju prilikom podizanja gotovine, plaćanja i razmjene valuta na putovanju u inozemstvu maksimalno smanjeni. Vrlo brzo je prerastao tu početnu ideju." (Bug.hr, 2019, str. 47).

Posljednjih je godina i među hrvatskim bankama primjetan trend priključivanja globalnoj Fin-Tech utrci. PBZ je još 2017. svim klijentima omogućila plaćanje u kombinaciji s njihovim karticama putem pametnih telefona i pametnih satova. Klijent dobiva virtualni novčanik u samom uređaju gdje pohranjuje podatke o svojoj kartici, a plaćanje vrši prislanjanjem mobilnog uređaja uz POS na prodajnom mjestu. Transakcije su brze, sigurne i jednostavne, ne zahtijevaju nikakva tehnička predznanja, a cjelokupnu instalaciju potrebnu za korištenje korisnici mogu odraditi iz svoje kuće (Brezak Brkan, 2017).

Jedan od bolje poznatih domaćih primjera internog razvoja Fin-Tech rješenja unutar banaka je Keks Pay, koji je osmislio interni tim Erste banke i interni Fin-Tech start-up u suradnji s vanjskim partnerima. Posljednji raspoloživi podaci govore kako Keks Pay ima više od 100.000 korisnika, čime je pretekao Revolut unutar svega par mjeseci od pokretanja usluge (Brezak Brkan, 2019). S obzirom na sve veći broj korisnika pametnih telefona, i ostale hrvatske banke uskoro planiraju uvođenje Apple Pay i Google Pay usluga.

Daljnjem širenju Fin-Tech rješenja u RH značajno doprinosi i donošenje Direktive o platnim uslugama PSD2 (payment service directive 2) na nivou EU, koja od 2019. omogućava pristup bazama bankovnih podataka i drugim poduzećima i organizacijama uz prethodno certificiranje i licenciranje od strane regulatora (HUB, 2019). Takvo okruženje gdje bankovni podaci osim u samim bankama koje ih prikupljaju, generiraju i obrađuju unutar svojih informatičkih sustava, omogućava da na standardiziran i siguran način korištenjem ICT-a, pristupaju i ostale Fin-Tech i Big-Tech kompanije, koje korisnicima omogućavaju puno brže, jednostavnije i efikasnije kreiranje novih inovativnih usluga. PSD2 direktiva znači bolji pregled osobnih financija i sigurnije, inovativnije, bolje, brže i povoljnije digitalne usluge kroz uvođenje dvije ključne inovacije - usluge pregleda računa (AIS) i usluge plaćanja (PIS).

To će uskoro omogućiti da umjesto različitih kartica, usluga internet i mobilnog bankarstva i tokena korisnik ima tek jednu aplikaciju, odnosno mobilni novčanik koji će objediniti usluge svih financijskih institucija i Fin-Tech kompanija. Takvoj budućnosti banke se već danas prilagođavaju, u cilju zadržavanja lojalnosti svojih klijenata.

\section{EMPIRIJSKO ISTRAŽIVANJE UTJECAJA FIN-TECH KOMPANIJA NA DIGITALNU TRANSFORMACIJU BANKARSTVA U REPUBLICI HRVATSKOJ}

Kako bi provjerili trenutnu situaciju u korištenju Fin-Tech rješenja i aplikacija na hrvatskom tržištu financijskih proizvoda te utvrdili razinu konkurentskog odnosa banaka i Fin-Tech kompanija, provedeno je kvalitativno istraživanje.

\subsection{Metodološki okvir istraživanja utjecaja Fin-Tech kompanija na digitalnu transformaciju bankarstva u Republici Hrvatskoj}

Istraživanje je provedeno primjenom dubinskog intervjua, s relevantnim sugovornicima iz područja bankarstva i Fin-Tech-a, koji su u odgovorni za unapređenje poslovnih procesa i 
njihovu digitalnu transformaciju. Među bankama su intervjuirani predstavnici iz Sberbank d.d., Addiko bank d.d. i Hrvatske poštanske banke d.d. Od prisutnih Fin-Tech kompanija na hrvatskom tržištu intervjuirani su predstavnici Modus Infinitum, Settle i Keks Pay. Intervjui su provedeni na temelju polustrukturiranog vodiča, dok je terenski dio istraživanja proveden između siječnja i ožujka 2020. g. Ukupan uzorak čini 10 sudionika prikazan u Tablici 1. Zbog njihove anonimnosti, umjesto osobnih imena dodijeljena im je opisna kategorija (A-J).

\section{Tablica 1. Sudionici intervjua}

\begin{tabular}{|l|c|}
\hline Poduzeće & Sudionik \\
\hline Sberbank d.d. & A, B, C \\
\hline Addiko bank d.d. & D, E \\
\hline Hrvatska poštanska banka d.d. & F \\
\hline Modus Infinitum d.o.o. & G, H \\
\hline Settle & I \\
\hline Keks Pay & J \\
\hline
\end{tabular}

Izvor: Provedeno istraživanje autora

\subsection{Rezultati istraživanja utjecaja Fin-Tech kompanija na digitalnu transformaciju bankarstva u Republici Hrvatskoj}

Kroz istraživanje su dobiveni stavovi na sljedeća istraživačkih pitanja:

1. Jesu li su banke i Fin-Tech kompanije prepoznale aktualni trend financijskih usluga usmjerenih na potrebe klijenata?

2. Prilagođavaju li se banke i Fin-Tech kompanije potrebama tržišta na optimalan način?

3. Mogu li banke biti lideri u digitalnoj transformaciji RH te mogu li to ostvariti sami ili tek u sinergiji s drugim bankama i cjelokupnim gospodarstvom?

Kako bi provjerili može li se bankarski sektor svemu tome brzo prilagoditi, ili ga čeka stagnacija i pad; koje su promjene već u tijeku i kakva je perspektiva unutar idućih 5 godina, te koji su očekivani ishodi digitalne transformacije bankarstva, odnosno koje su to ključne tehnologije koje bankarstvo mora prihvatiti i uključiti u svoje poslovanje.

\subsubsection{Jesu li su banke i Fin-Tech kompanije prepoznale aktualni trend financijskih usluga usmjerenih na potrebe klijenata?}

Aktualni trendovi temeljeni na potrebama klijenata jasno su prepoznati. Sudionici digitalnu transformaciju vide kao priliku i smatraju kako se pravilnim odabirom strategije i partnera može ostvariti sinergija koja će ojačati financijsko poslovanje i postaviti temelje za naknadno širenje digitalne ponude. Primjetan je fokus svih sudionika tek na Fin-Tech debit i platni promet, odnosno na domaća i međunarodna plaćanja, dok su ostale Fin-Tech usluge tek u planu realizacije u budućem razdoblju. Citati na osnovu kojih su sumirani ovi stavovi banaka i Fin-Tech kompanija dani su u Tablici 2. 


\section{Tablica 2. Stavovi o prepoznavanju aktualnog trenda financijskih usluga i potreba klijenata}

\begin{tabular}{|c|c|}
\hline Trendovi & $\begin{array}{l}\text { „Digitalna transformacija u svijetu je barem } 5 \text { godina ispred nas." (A) „Raskorak } \\
\text { nadoknađujemo razvijanjem novih aplikacija i proizvoda na dnevnoj bazi." (B) } \\
\text { „Tržište je postalo otvoreno i za financijske usluge s drugih područja s obzirom da je } \\
\text { Fin-Tech ponuda globalna, a bankarska lokalna." (D) } \\
\text { „Bankarski sektor može uloviti priključak sa svjetskim trendovima s obzirom da } \\
\text { postoje već gotova i u svijetu isprobana rješenja." (F) } \\
\text { „Banke su spori i jako regulirani sustavi koji se tradicionalno teško i pažljivo } \\
\text { prilagođavaju novostima na tržištu, dok Fin-Tech kompanije nemaju taj teret i puno } \\
\text { su brži i fleksibilniji u primjeni novih tehnologija." (G) } \\
\text { „Financijsko poslovanje će biti puno brže i jednostavnije te više okrenuto potrebama } \\
\text { klijenata." (H) }\end{array}$ \\
\hline $\begin{array}{l}\text { Digitalna } \\
\text { transformacija je } \\
\text { prilika }\end{array}$ & $\begin{array}{l}\text { „Fin-Tech pruža toliko mogućnosti za razvoj gospodarstva u cjelini da ih je teško sve i } \\
\text { predvidjeti." (A) } \\
\text { „Ovo je odlična prilika da kao država preskočimo nekoliko godina razvoja i odmah } \\
\text { usvojimo digitalne i mobilne modele poslovanja." (B) } \\
\text { „To je prilika i za mala visokotehnološka poduzeća da se priključe digitalnoj } \\
\text { transformaciji u vrijeme dok je u ovoj razvojnoj fazi." (E) } \\
\text { „To je svakako uzbudljiva prilika za razvoj novih i modernih financijskih rješenja, } \\
\text { krojenih po mjeri klijenata, a ne banke." (H) } \\
\text { "Najveća prednost je jednostavnost i brzina korištenja usluga te lak prelazak na neku } \\
\text { drugu uslugu koja klijentu više odgovara." (J) }\end{array}$ \\
\hline Sadašnji projekti & $\begin{array}{l}\text { „Fokus je još uvijek na platnom prometu i zamjeni fizičkih kartica." (D) } \\
\text { „Objedinjuju se mogućnosti platne i loyalty kartice u jednu aplikaciju na mobitelu za } \\
\text { sve financijske institucije i potrebe na jednom mjestu." (G) } \\
\text { „Fokus nam je loyalty program s partnerima koji bi u idućoj fazi proširili s novim } \\
\text { digitalnim mogućnostima." (H) } \\
\text { „Osim platnog prometa koji je postao Fin-Tech mainstream, intenzivno se radi na } \\
\text { integraciji kripto valuta u svakodnevno poslovanje i financiranje." (I) }\end{array}$ \\
\hline Budući projekti & $\begin{array}{l}\text { „Digitalni novčanik (vallet) je nešto što će za } 5 \text { godina svi koristiti, stoga radimo na } \\
\text { projektu implementacije jednog svjetskog Fin-Tech rješenja koje donosi cjeloviti } \\
\text { sustav kao nešto potpuno novo na našem tržištu." (A) } \\
\text { „Radimo na implementaciji poznatog svjetskog Fin-Tech rješenja u području platnog } \\
\text { prometa i transakcijskog poslovanja." (C) } \\
\text { „Usredotočeni smo na daljnji razvoj već postojećih mogućnosti sustava i širenje } \\
\text { mreže maloprodajnih mjesta, restorana i kafića koji bi prihvaćali naše usluge } \\
\text { plaćanja." (I) } \\
\text { „Fin-Tech krediti su budućnost financiranja i tu još ima prostora za daljnji razvoj." (J) }\end{array}$ \\
\hline
\end{tabular}

Izvor: Provedeno istraživanje autora 


\subsubsection{Prilagođavaju li se banke i Fin-Tech kompanije potrebama tržišta na optimalan način?}

Razina tehnološke opremljenosti banaka i Fin-Tech kompanija je na zadovoljavajućoj razini. Sudionici intervjuiranja smatraju kako će u budućnosti biti potrebne tek male nadogradnje postojećih sustava koje će omogućiti maksimalnu iskorištenost potencijala digitalne transformacije financijskog sektora. Nedavno uvedena direktiva PSD2 otvara digitalna vrata svim zainteresiranim stranama da na jednostavniji i transparentniji način iskoriste mogućnost razvoja aplikacija i korištenja novih modela inovativnih financijskih proizvoda. Dok dio sudionika smatra kako će se portfelj usluga samo nadopuniti i kako su u svojoj suštini one komplementarne, drugi dio sudionika smatra kako će u idućih 5 godina postojeće prvenstveno platno prometne usluge banaka i kartičarskih kuća biti zamijenjene posve novim modelima.

Svi sudionici su suglasni oko prepoznavanja osnovne prednost Fin-Tech rješenja i digitalne transformacije kroz olakšavanje transparentnog, brzog i jednostavnog provođenja transakcija te objedinjavanje više financijskih usluga na jednom mjestu, što je u potpunosti prilagođeno preferencijama krajnjih korisnika. Većina tih usluga je za korisnika besplatna ili povoljnija od postojećeg komplementarnog proizvoda ili usluge neke druge banke.

Kao trenutačni nedostatak izdvaja se relativno mala rasprostranjenost maloprodajnih mjesta koje prihvaćaju inovativne modele plaćanja te još uvijek nedovoljna spremnost tržišta na njihovo masovno korištenje. Uočen je i generalni nedostatak znanja klijenata o novim financijskim mogućnostima, s obzirom da se osim u ograničenom dijelu platno prometnih transakcija nedostaje interes prema npr. kriptovalutama, pametnim ugovorima ili općenito Blockchain mogućnostima. Osobito je nizak interes za Fin-Tech kreditne mogućnosti koje predstavljaju veliki potencijal posebno za gospodarstvo. Pored toga, u $\mathrm{RH}$ evidentno postoje i pravne prepreke s obzirom da dobar dio novih financijskih usluga koje su u svijetu već u odmakloj fazi razvoja i primjene, kod nas i dalje nisu zakonski definirane i primjenjive. Potvrdu ovakvog stava sudionici vide u činjenici da neki akteri na našem tržištu nisu podložni ograničenjima hrvatskog zakonodavnog okvira (npr. Ferratum banka - Malta).

U skoroj budućnosti, svi sudionici očekuju rast interesa za korištenje novih financijskih usluga, prvenstveno među mlađim klijentima i novim tehnološki naprednim poduzećima. Dolazak globalnih igrača i njihovih financijskih proizvoda na naše tržište, bilo kao samostalnih proizvoda i usluga (npr. Revolut) ili kao dio postojećih bankarskih sustava (Apple i Google Pay) dodatno će ubrzati te promijene. Citati na osnovu kojih su sumirani ovi stavovi banaka i Fin-Tech kompanija dani su u Tablici 3. 
Tablica 3. Stavovi sudionika o prilagođavaju potrebama tržišta na optimalan način

\begin{tabular}{|c|c|}
\hline $\begin{array}{l}\text { Opremljenost } \\
\text { potrebnom } \\
\text { tehnologijom }\end{array}$ & $\begin{array}{l}\text { „Infrastruktura je odlična, širokopojasni pristup internetu je dostupan većini što je } \\
\text { osnovi preduvjet za implementaciju novih usluga." (A) } \\
\text { "Penetracija osobnih računala, internet bankarstva i mobitela, dovoljna je osnova za } \\
\text { buduće digitalne proizvode i usluge koje im možemo ponuditi." (B) } \\
\text { "Tehnologija je dostupna, svi se trebamo usmjeriti na unapređenje znanja i vještina te } \\
\text { oblikovati obrazovni sustav kako bi buduće generacije pripremili za rad na inovativan } \\
\text { i prilagodljiv način." (H) } \\
\text { „Uvođenjem } 5 \mathrm{G} \text { mreže u narednih } 5 \text { godina RH će biti spremna za sve izazove u } \\
\text { području financijskih tehnologija." (J) }\end{array}$ \\
\hline & $\begin{array}{l}\text { "Neke od novih usluga sigurno će nadopuniti postojeći portfelj banaka, kreirajući } \\
\text { ponudu sličnu konkurenciji u okruženju." (A) } \\
\text { "Postoji još dosta prostora kako bi se postojeći proizvodi i usluge nadogradili i } \\
\text { nadopunili s novim isključivo digitalnim uslugama." (C) } \\
\text { "Inovativne Fin-Tech usluge u potpunosti će preokrenuti funkcioniranje i banaka i } \\
\text { klijenata, a postojeće usluge zamijenit će bolja rješenja." (G) } \\
\text { "Kada se jednom prepoznate prednosti Fin-Tech rješenja, više se nećete htjeti vratiti } \\
\text { na spore i stare sustave klasičnog internet bankarstva." (I) }\end{array}$ \\
\hline Prednosti i koristi & $\begin{array}{l}\text { „Brzina i prilagodljivost novih rješenja koja se mogu nadograđivati novim uslugama } \\
\text { po potrebi." (D) } \\
\text { "Uz pametni telefon, usluge su dostupne uvijek i svugdje, on postaje središte } \\
\text { financijskog života s kojim se mogu obavljati sva plaćanja, prijenosi, oročenja pa i } \\
\text { zahtjevi za kredit, bez odlaska u banku. Pored toga, PSD2 regulativa je otvorila vrata } \\
\text { za razvoj i implementaciju novih aplikacija." (E) } \\
\text { „Maloprodaja se tek treba uvjeriti u isplativost prihvaćanja novih načina plaćanja, } \\
\text { jer im donose značajne uštede u odnosu na uobičajene provizije kartičarskih kuća i } \\
\text { banaka." (H) } \\
\text { „Jednostavnost upotrebe - kada ručak platite mobitelom, a trošak podijelite s } \\
\text { kontaktom iz imenika, korištenje više kartica i banaka, upisivanje IBAN-a te plaćanje } \\
\text { naknada za prijenos, odjednom vam više neće biti prihvatljivi!" (I) } \\
\text { "Usluge su najčečće besplatne za klijenta, što banke rijetko primjenjuju, čime ukupan } \\
\text { trošak financijskog poslovanja klijentu postaje povoljniji." (J) }\end{array}$ \\
\hline $\begin{array}{l}\text { Nedostaci i } \\
\text { prepreke }\end{array}$ & $\begin{array}{l}\text { „Uska mreža maloprodajnih mjesta koja primaju nove oblike plaćanja." (A) } \\
\text { „Kako bi što prije izašli na tržište, pojavljuju se poluproizvodi što klijente usmjerava } \\
\text { prema renomiranim bankama. Susrećemo se i s konkurencijom koja nije pod } \\
\text { hrvatskom jurisdikcijom, niti ih nadzire HNB, a uredno posluju i plasiraju pozajmice } \\
\text { pod upitnim uvjetima za klijente." (B) } \\
\text { "Pravna regulativa zaostaje za razvojem tehnologije." (C) } \\
\text { "Sigurnost, hakerski napadi i iracionalni strah od gubitka sredstava." (D) } \\
\text { "Osim djelomično u platni promet, u druge segmente Fin-Tech u RH nije ušao, što } \\
\text { pokazuje nedostatak hrabrosti i naprednog razmišljanja, ali i prilika za onoga tko bi } \\
\text { prvi krenuo u tom smjeru." (G) } \\
\text { "Natjecanje s velikim sustavima, visokim troškovima i malim timovima." (H) } \\
\text { "Nepovjerenje prema novim poslovnim modelima koji su drugdje puno bolje } \\
\text { prihvaćene. Većina Hrvata zna vrlo malo ili ništa o kriptovalutama, a poduzeća ni ne } \\
\text { razmišljaju o novim načinima financiranja svog poslovanja, osim onog tradicionalnog } \\
\text { s bankama." (I) }\end{array}$ \\
\hline
\end{tabular}

Izvor: Provedeno istraživanje autora 


\subsubsection{Mogu li banke biti lideri u digitalnoj transformaciji RH te mogu li to ostvariti sami ili tek u sinergiji s drugim bankama i cjelokupnim gospodarstvom?}

Utjecaj globalnih igrača u Fin-Tech, odnosno Big-Tech financijskom području iznimno je jak što ograničava daljnji razvoj domaćih Fin-Tech kompanija na lokalnom tržištu. Zbog svoje veličine, količine raspoloživog kapitala i zbog generalne percepcije sigurnosti njihova poslovanja, banke će se generalno dobro prilagoditi i mogu postati lideri digitalne transformacije financijskog sustava jednostavno. Spektar novih financijskih usluga za sada uvode oprezno i konzervativno, primarno kroz nadogradnju platno prometnih i transakcijskih usluga te širenja digitalnih novčanika koji bi objedinio sve financijske usluge koje klijenti koriste (svih banaka i svih Fin-Tech rješenja). Daljnji razvoj njihovog portfelja donijet će bolje mogućnosti predviđanja financijskog ponašanja klijenata u svrhu određivanja kreditnih boniteta i skoringa na kojima bi se temeljilo odobrenje kredita, kreditnih limita kartica i sl. U nastavku to će omogućiti ciljani pristup svakom klijentu s personaliziranom ponudom isključivo za njega i to u trenutku kada mu je ona potrebna. Otvorenim ostaje kako uskladiti prava na prikupljanje i obradu osobnih podataka u skladu s GDPR-om, pravnu identifikaciju elektronskog potpisivanja i ostalih još uvijek nedovoljno definiranih detalja.

Većina banaka svoju strategiju vide u udruživanju s postojećim Fin-Tech i Big-Tech igračima i njihovim postojećim rješenjima, a tek manji dio njih smatra da je kvalitetan interni i samostalan razvoj bolji pristup u njihovoj digitalnoj transformaciji. Fin-Tech kompanije jasno izražavaju namjeru preuzimanja djela poslovanja banaka i zaoštravanja konkurentskih odnosa, nego što su to banke spremne priznati. Vjeruju da se mogu bolje profilirati radeći direktno s maloprodajom ili sa svim bankama, nego vezavši svoje poslovanje za određenu banku s kojom bi imali partnerski odnos.

Upotreba Fin-Tech usluga u projekciji idućih 5 godina je svakodnevna i široko prihvaćena. Većina malih transakcija obavljat će se putem pametnih uređaja, proširit će se mogućnosti plaćanja na rate, dozvoljena prekoračenja, pred odobrene pozajmice i sl. Potencijal se nalazi i u širenju prihvaćanja kripto valuta i interesa poduzetnika za mogućnosti financiranja kroz izdavanje kripto tokena i sl. Za privatne klijente korištenje kriptovaluta još neko vrijeme neće biti opće prihvaćeno sredstvo plaćanja i trgovanja. Ponuda privatnim klijentima bit će proširena poslovnim modelima pred skoringa i pred odobrenja, na osnovu analize podataka klijenta i njegovih navika korištenja. Posuđivanje novca privatne osobe drugoj osobi, putem za to namijenjenih platformi neće biti rašireno, pa će banke tu i dalje držati primat. Citati na osnovu kojih su sumirani ovi stavovi banaka i Fin-Tech kompanija dani su u Tablici 4. 


\section{Tablica 4. Mogu li banke postati lideri u digitalnoj transformaciji, te kako to mogu ostvariti}

\begin{tabular}{|c|c|}
\hline Sinergija & $\begin{array}{l}\text { „Strana konkurencija zahvaća svoj dio tržišta u suradnji s bankama." (A) } \\
\text { „Za sada uglavnom vidimo primjere sinergije s bankama. Google Pay i Apple Pay sa } \\
\text { PBZ-om, Settle sa Sberbankom i sl. I same Fin-Tech kompanije su tržište procijenile } \\
\text { tradicionalnim, pa prostor za razvoj vide u suradnji s bankarskim sustavom." (B) } \\
\text { „Suradnja s uspješnim Fin-Tech kompanijama je brže i prihvatljivije rješenje." (C) } \\
\text { „Vlastiti razvoj ima svoje prednosti, no banke uglavnom nemaju spremne resurse kako } \\
\text { bi svoje projekte odradile u cijelosti same, osim toga nije mudro samostalno ulagati u } \\
\text { resurse kada za to postoje specijalizirane kompanije. Suradnja je puno brže i u konačnici } \\
\text { jeftinije rješenje." (D) } \\
\text { „Udruživanje u traženju partnera u maloprodaji koja prihvaćaju nova rješenja, su } \\
\text { presudna za uspjeh svih na tržištu." (I). }\end{array}$ \\
\hline Vlastiti razvoj & $\begin{array}{l}\text { „Ovo je idealan trenutak za promišljeni i pametni nastup na tržištu kako bi uzeli svoj „dio } \\
\text { kolača" od velikih banaka. Na dobrom smo putu da se uskoro banke zabrinu nad svojim } \\
\text { sporim prilagođavanjem i razumijevanjem klijenata." (G) } \\
\text { "Kad ne ovisite o bankama, možete pametnim i fleksibilnim aplikacijama i uslugama } \\
\text { samostalno konkurirati. Možete skratiti vrijeme reakcije i isprobati neke ideje koje } \\
\text { unutar velikog i krutog sustava nije lako „progurati." (I) } \\
\text { „Vlastiti razvoj je težak put, ali pruža slobodu iskušavanja granica i mogućnosti koje } \\
\text { tehnologija pruža čime se dokazuje da i relativno mali tim visokostručnih djelatnika, } \\
\text { može u kratko vrijeme dati odlične rezultate. Skalabilni sustavi, prilagodljivi različitim } \\
\text { poduzećima temelj su za dalje globalno širenje poslovanja." (J) }\end{array}$ \\
\hline $\begin{array}{l}\text { Projekcija } \\
\text { budućnosti } \\
\text { i širenje } \\
\text { spektra usluga }\end{array}$ & $\begin{array}{l}\text { „Plaćanje digitalnim novčanikom i općenito mobilnim uređajima biti će sveprisutno kao } \\
\text { što je danas plaćanje karticom. Analiza navika i urednosti klijenta u otplati financijskih } \\
\text { obveza omogućava lakše upravljanje rizicima i automatizira skoring klijenta, što } \\
\text { omogućava širenje usluga u smjeru ciljanih ponuda klijenata, za koje se neće morati } \\
\text { prolaziti cijela procedura odobravanja rizika." (A) } \\
\text { „Budućnost je objedinjavanje svih potreba klijenta u jednoj aplikaciji. Zašto klijent } \\
\text { aplikacijom ne bi istovremeno pozvao i platio uslugu Uber-a, usput naručio dostavu } \\
\text { hrane i podijelio trošak sa prijateljima koji ga već čekaju - kroz nekoliko klikova! Sve } \\
\text { bi više poduzeća moglo razmatrati i financiranje poslovanja i alternativnim kanalima, } \\
\text { pogotovo u djelatnostima prema kojima su banke tradicionalno nepovjerljivije." (B) } \\
\text { "On line trgovina će biti objedinjena, tako da digitalni novčanik doista postaje } \\
\text { jedinstveno mjesto za obavljanje svih plaćanja." (C) } \\
\text { "Upitno je u kojem obliku će banke početi masovnije koristiti kripto valute, ali očekuje se } \\
\text { značajni porast njene potražnjei korištenja." (D) } \\
\text { "Širenje spektra usluga ide u smjeru back office poslovanja, gdje postoji velik prostor za } \\
\text { implementaciju Blockchain tehnologije i primjene pametnih ugovora." (E) } \\
\text { „Drastično će se smanjiti broj odlazaka u banku i traženja odobrenja dozvoljenih } \\
\text { prekoračenja ili limita po karticama. Temeljem analize prihoda i financijske odgovornosti } \\
\text { automatski biti ponuđeno rješenje koje će se jednostavno prihvatiti otiskom prsta. Male } \\
\text { pozajmice i krediti manjih iznosa će biti dostupni kroz aplikacije, dok će se u banku ići još } \\
\text { jedino po stambene kredite." (F) }\end{array}$ \\
\hline
\end{tabular}

Izvor: Provedeno istraživanje autora 


\subsection{Rasprava istraživanja utjecaja Fin-Tech kompanija na digitalnu transformaciju bankarstva u Republici Hrvatskoj}

Digitalna transformacija financijskog sektora u svijetu je u punom jeku. Mali start-upovi se ravnopravno natječu s velikim Fin-Tech i Big-Tech kompanijama te praktički nema segmenta financijskog poslovanja koji nije obuhvaćen velikim promjenama i nužnim prilagodbama na novu digitalnu paradigmu. Bankarski sustav $\mathrm{RH}$ je pogođen inicijalnim ulaskom prvenstveno Big-Tech kompanija, koje kroz svoju primarnu djelatnost raspolažu s ogromnom bazom klijenata i još većim iskustvom u upravljanju njihovim potrošačkim navikama i kreiranju zadovoljstva i lojalnosti. Banke su na vrijeme prepoznale potencijal koji im digitalna transformacija donosi. Pokazale su visok stupanj razumijevanja rizika i te su se i same počele ubrzano prilagođavati novim trendovima kako bi i dalje ostale najvažniji čimbenik i sudionik hrvatskog financijskog tržišta.

Rezultat provedenog istraživanja ipak ukazuje da $\mathrm{RH}$ u pojedinim segmentima zaostaje za globalnim razvojem financijskih usluga. U segmentu platnog prometa i transakcijskog djela financijskog sektora, primjećuje se napredak i inicijativa od strane banaka kako bi i sami postali nositelji digitalne transformacije. Ta inicijativa temelji se na osviještenosti važnosti zadovoljstva i lojalnosti njihovih klijenata, koji tako postaje glavna prepreka za prihvaćanje alternativnih ponuda koje bi im Fin-Tech kompanije mogle ponuditi van uobičajenog bankarskog sustava.

Ulazak i budućnost Fin-Techa u svijet hrvatskog financijskog sektora je neizbježna te banke uz takav pristup klijentima mogu ravnopravno sudjelovati, pa čak i biti lideri u procesu digitalne transformacije.

\section{ZAKLJUČAK}

Kao zaključak provedenog istraživanja utjecaja Fin-Tech kompanija na digitalnu transformaciju bankarstva u Republici Hrvatskoj izdvajaju se potvrdni stavovi na postavljena istraživačka pitanja:

- $\quad$ Banke u RH su svjesne prilika koje im digitalna transformacija poslovanja donosi, ali i opasnosti koje im Fin-Tech kompanije predstavljaju. Opasnosti koje banke najčešće prepoznaju u poslovanju Fin-Tech kompanija su dostupnost klijentima, predviđanje njihovih individualnih želja i potreba, maksimalna fleksibilnost te racionalizacija troškova i smanjenje opsega klasičnog bankarskog poslovanja kroz poslovnice. Unatoč što su im Fin-Tech kompanije realna prijetnja, banke ih smatraju izazovom kojem uz započete prilagodbe mogu zadržati svoju dobru poziciju na domaćem financijskom tržištu.

- Klijenti su svjesni alternativa i prednosti koje im Fin-Tech donosi na financijskom tržištu. Sve više klijenata uočava alternative zbog čega raste broj korisnika nekih od dostupnih Fin-Tech financijskih proizvoda i usluga iz domaće i globalne ponude. Klijenti prepoznaju prednosti inovativnih financijskih proizvoda i usluga u vidu fleksibilnosti i dostupnost uz besplatno korištenje ili barem uz značajno niže troškove u odnosu na postojeće bankarske usluge. Toga su svjesne i banke i Fin-Tech kompanije kojima je to temelj strategije daljnjeg širenja poslovanja u RH. 
- Domaće i strane Fin-Tech kompanije kontinuirano rade na razvoju i poboljšavanju svojih digitalnih platformi te tako aktivno sudjeluju u zadržavanju postojećih i privlačenju novih korisnika. Kupci se sve više oslanjaju na digitalne usluge te rado koriste rješenja koja im nude Revolut, Keks Pay, Google Pay, Settle, Apple Pay, Amazon Pay, PayPal i AliPay. lako je njihov broj korisnika još uvijek manji od klasičnih bankovnih usluga, rast je očit i svi su sudionici svjesni nužnosti transformacije svog poslovanja kako bi očuvali poziciju koju trenutno posjeduju.

- Banke mogu ravnopravno sudjelovati u digitalnoj transformaciji financijskog sustava te mogu biti predvodnici i nositelji te transformacije uglavnom u sinergiji s prisutnim Fin-Tech ili Big-Tech kompanijama, predstavljajući zajednička digitalna rješenja. Na taj način obje strane koriste pozitivne efekte sinergije. Banke proširuju ponudu kvalitetnim i pouzdanim proizvodom, a Fin-Tech kompanije dobivaju pristup velikim bazama klijenata. Međusobno koriste prednosti velikog i iskusnog partnera koji poznaje specifičnosti financijskog tržišta.

- Fin-Tech kompanije su u uzletu na globalnom tržištu te i na domaćem tržištu neovisno o aktualnim bankarskim prilagodbama i njihovoj ubrzanoj digitalnoj transformaciji, mogu uzdrmati postojeći financijski sustav. U slučaju da banke neće biti spremne na pravovremeni odgovor, Fin-Tech kompanije će im zaprijetiti preuzimanjem značajnog dijela tržišta. Ukoliko pak na vrijeme provedu sve planirane aktivnosti i adaptiraju svoje poslovanje u smjeru inovativnog načina i obrazaca razmišljanja te percipirajući potrebe svojih klijenata, banke još uvijek imaju mogućnost nametnuti se kao lideri digitalne transformacije financijskog sektora.

S obzirom na ograničeni broj sugovornika provedenih intervjua, prikupljeni rezultati nameću potrebu dodatnih istraživanja hrvatskog financijskog tržišta, kao i planova za daljnji razvoj Fin-Tech proizvoda i usluga. Ta buduća istraživanja svoj fokus s banaka i FinTech kompanija mogu usmjeriti na segmente tržišta koji trenutno nisu u fokusu (kreditiranje i kriptovalute), a potencijalno mogu ostvariti eksponencijalan rast ne samo broja korisnika, već i povećanja profita onima koji budu kreirali ponudu u tom smjeru. Pored toga, narednim istraživanjem bi trebalo obuhvatiti i financijsko djelovanje središnje banke (HNB) i Ministarstva financija te razmotriti mogućnosti primjene Fin-Tech rješenja u svrhu upravljanja državnim financijama, tokovima novca, međunarodnim i tuzemnim transferima, fiskalnom politikom i sl. Tijekom aktualne pandemije Covid 19, potvrđena je važnost pojedinih Fin-Tech rješenja koja su se pokazala kao jedna od iznimno korisnih opcija, što dodatno potiču digitalnu transformaciju globalnog, pa i hrvatskog financijskog sektora. 


\title{
THE IMPACT OF FIN-TECH COMPANIES ON THE DIGITAL TRANSFORMATION OF BANKING IN THE REPUBLIC OF CROATIA
}

\author{
Sanja Bračun, PhD \\ Zagreb University of Applied Sciences \\ Vrbik 8, Zagreb, Croatia \\ Phone number: +38599263 0703, e-mail: sbracun1@tvz.hr \\ Krešimir Turkalj, MSc \\ Sberbank \\ F. Račkog 9, Zagreb, Croatia \\ Phone number: +38591 639 3443, e-mail: turkalj.kresimir@gmail.com
}

\section{ABSTRACT}

The digital transformation of the financial sector is making strong progress in the global market. Fin-Tech companies are increasingly competing with, or even completely bypassing the existing financial sector, primarily banks. This trend is evident also in the Republic of Croatia, where new companies and their innovative financial products are increasingly emerging. In order to verify the readiness of Croatian banks to digital transformation and the implementation of new products and services, a qualitative research has been carried out (interviews with ten relevant respondents in the banking and Fin-Tech companies) to check the impact of Fin-Tech companies outside the banking sector on the banking system itself. During the research, particular attention was given to assessing whether banks and Fin-Tech companies on the Croatian market recognized the current needs of their clients, how well they adapted to their needs and whether banks can continue to be leaders in the digital transformation of the Republic of Croatia. As far as customer needs are concerned, a minor part of the respondents believe that the portfolio of banking services will merely be supplemented with new products and services, while most of the respondents believe that in the next 5 years the existing money transfer and card-based banking services will be replaced by completely new business models. Bank representatives note the strong influence of Fin-Tech companies on the global market but believe they still have a minor influence in the Republic of Croatia. They also believe that the banks are generally adapting well to the new situation and will continue to be leaders of digital transformation. They will retain this position primarily because of their size and the amount of capital they have at disposal in the process of building the perception of the safety of their business, which remains extremely important for Croatian clients. Based on research results, recommendations have been made for further activities related to digital transformation, which banks should implement in order to maintain a leading position on the Croatian financial services market.

Keywords: banks; digital transformation; Fin-Tech companies; Blockchain 


\section{LITERATURA}

1. AtKearney, E. (2014). Going digital: The banking transformation road map. Preuzeto s https:// www.atkearney.com/documents/10192/5264096/Going+Digital+-+The+Banking+Transformat ion+Road+Map.pdf/60705e64-94bc-44e8-9417-652ab318b233 (30.3.2020.)

2. Brezak Brkan, I. (2019). Keks Pay: Praktičan primjer kako razviti uspješan interni 'startup' (čak $i$ ako ste banka). Preuzeto s https://www.netokracija.com/keks-pay-erste-banka-156677 (30.3.2020.)

3. Brezak Brkan, I. (2017). PBZ predstavio novo digitalno bankarstvo za Apple Watch, iPhone i Android. Preuzeto s https://www.netokracija.com/mpbz-iphone-android-apple-watch-141240 (30.3.2020.)

4. Bug.hr (2019). Revolut ima već pedeset tisuća korisnika u Hrvatskoj, a sada uvodi i trgovanje dionicama, Preuzeto s https://www.bug.hr/biznis/revolut-ima-vec-pedeset-tisuca-korisnikau-hrvatskoj-a-sada-uvodi-i-trgovanje-11555 (30.3.2020.)

5. Desai, F. (2015). The Evolution Of Fintech, Preuzeto s https://www.forbes.com/sites/falgunidesai/2015/12/13/the-evolution-of-fintech/\#66d5399f7175 (28.4.2020.)

6. Hrvatska udruga banaka (2019). Što je PSD2 direktiva? Preuzeto s https://www.hub.hr/hr/stoje-psd2-direktiva (30.3.2020.)

7. KPMG International (2019). Global Analysis of Investment in FinTech. Preuzeto s https:// home.kpmg/xx/en/home/campaigns/2019/07/pulse-of-fintech-h1-19-global-trends.html (30.3.2020.)

8. Krstić, N. i Tešić, D. (2016). Digitalna transformacija bankarskog poslovanja - opasnost ili prilika? Bankarstvo, 45( 2), str. 12-33.

9. Zachariadis, M., Vinogradov, D. i Kokas S. (2020). Which Banks Smooth and at What Price? Preuzeto $s$ https://docs.google.com/viewer?a=v\&pid=sites\&srcid=ZGVmYXVsdGRvbWFpbnx6YW NoYXJpYWRpc21hcmlvc3xneDo1ZGQ3YzhmNzczZWQxMjg1 (30.3.2020.)

10. Wonglimpiyarat J. (2017). FinTech banking industry: a systemic approach. Foresight, 19(6), str. 590-603, Preuzeto s https://doi.org/10.1108/FS-07-2017-0026 (30.3.2020.) 